\title{
The Contribution of Financial Sector Development for Economic Growth in East Africa
}

\author{
Worku R. Urgaia $^{1}$ \\ ${ }^{1}$ Department of Economics, Addis Ababa University, Ethiopia. \\ Correspondence: Worku R. Urgaia, Department of Economics, Addis Ababa University, Ethiopia.
}

Received: December 16, 2015

Accepted: January 5, 2016

Available online: February 26, 2016

doi:10.11114/aef.v3i2.1251

URL: http://dx.doi.org/10.11114/aef.v3i2.1251

\begin{abstract}
The study empirically analyses the contribution of Financial Sector Development to Economic Growth in East Africa over the period 1975-2014. A five variable dynamic panel Fully Modified Ordinary Least Squares FMOLS is employed to estimate the short-run and long-run parameters. The fluctuations of Financial Sector and Economic Growth are mainly explained by their shocks in the long run and the proportion in the variance slightly decreases over time while the accumulated response of Economic Growth to Financial Sector increases. The gain of this study, therefore, provides the Supply and Demand Leading Hypotheses; means Financial Sector accelerates and augments the economic growth and the Economic Growth enhances the Development of Financial Sector. The implications drawn from this study are the reforms in the Financial Sector; inclusiveness of Financial System and effective vigorously pursued expansionary monetary policy, which directs the economy, could be a comprehensive beneficial to the study countries.
\end{abstract}

JEL Classification: E4, E44

Keywords: Financial Sector, Economic Growth, Panel Cointegration, FMOLS and East Africa

\section{Introduction}

The relationship between Financial Sector Development FSD and Economic Growth has increasingly attracted a number of researchers across the globe because of institutional differences and variation in capital allocation between and within economies. Financial Sectors can be considered as factors, policies and institutions that lead to effective financial markets and access to capital and financial services (World Economic Forum, 2012). A rapid economic growth must transform into sustained and inclusive development, through on development strategies that foster economic diversification, create jobs and reduce inequality and poverty according to (UN and African Union, 2014) report. However, Africa's recent growth remains below potential and has failed to translate into meaningful job creation and its GDP growth rate slowed from 5.7 per cent in 2012 to 4.0 per cent in 2013, against developing economies' average of 4.6 per cent(United Nations Economic and Social Council Commission for Africa and African Union (2014, p.14) report.

Capital markets in the financial systems can also contribute to growth by raising long-term finance for productive investment, diversifying investors' risks and improving the allocation of funds (DFID, 2004). Nevertheless, in the East Africa economies, capital markets are underdeveloped, constrained by out dated legal frameworks, lack of capacity and regulatory framework, poor supervision and less market shares. The East Africa has a difficulty to access the banking system, which ties the biggest component of the financial sector. The financial activity in the region is by far infant and characterized by the monopolistic or oligopolistic behaviour of a few commercial banks, owned by governments. More importantly; the financial systems have remained highly exclusive and this exclusiveness is a primarily result of market failures that make the provision of financial services to lower-income groups as empirical evidences by (Thorsten and Samuel, 2013; Ali and Emerta 2012).

The contribution of financial sector development and capital market to economic growth are important tools because they promote economic growth, develop private sectors, increase liquidity to mobilize local savings, enhance bank competitions and develop a greater diversity of financial institutions (Paul, 2004). Financial sector development and its services would expect to play an essential role in improving the livelihoods. However, this is not the case in the East African region. For instance, there is an increase in the financial risk associated with growing stock of external debt and shortage of foreign exchange in Ethiopian (Haile and James, 2014), lack of export financing and long-term credit 
(Wolday and David, 2010) and very low level of the financial inclusiveness and lack of physical access(Girma, 2012) and raising the paid-in capital about 566 per cent for commercial banks and 900 per cent for microfinance institutions by the National Bank of Ethiopia (Genet,2014).

Despite the fact that the Kenyan innovations in financial access undertaken in the system through Safaricom's M-Pesa, the world's leading mobile phone based microfinance institution for payments provider is a remarkable (Susan, 2014) except the financial system volatility in credit markets and macroeconomic instability. The problems mentioned above are similar to other countries in the region. For instance; undiversified, relatively high lending rates, extremely low insurance penetration and a scarcity of long term debt in Rwandan finance system; largely excessive government interference in the management of financial institutions of Tanzania and sharply curtailed and the neglect of prudential regulation leads to mismanagement in Uganda are among others, see (United Nations, 2014 report; Kessy, 2011 and Martin, 1996).

Similar empirical studies were also conducted in particular by (Athenia and Alfred, 2014) Banking sector development and economic growth: Evidence from Zimbabwe; (Montfo et al. 2013) Banking in Sub-Saharan Africa: Challenges and Opportunities; (Ndlovu, 2013) Financial Sector Development and Economic Growth: Evidence from Zimbabwe; (Nicholas,2008) Financial Development in Kenya; (Thorsten and Samuel, 2013) on Financial Sector Development in Africa; (Ali and Emerta, 2012) Financial Sector Development in the IGAD Region; (David,2012) Policy Innovations to Improve Access to Financial Services in Developing Countries: Learning Kenya; (Ali, 2012) Banking Sector Development and Economic Growth; (Paul, 2004) Capital Market and Financial Sector Development in Sub-Saharan Africa and (Easterly and Levine, 1997) Africa's Growth Tragedy, policies and Ethnic divisions have similar arguments on African wide and other developing countries in general.

This study extensively describes a number of controversial empirical studies whether the FSD has a positive impact on Economic Growth. Evidences from empirical studies show deeper, broader and better functional financial sector development can stimulate economic growth (Ugbaje and Edez, 2014; Montfort, et.al. 2013; Levine and Zervos, 1996 and Pagano, 1993). However, (Lucas, 1988 and Stern, 1989) suggest there is no relationship between financial sector development and economic growth. Therefore, looking at the mixed results and different views among the evidences of empirical studies, we explore the existing theory in organizing an analytical frame work to assess the effectiveness and importance of the FSD to the economic growth and the economic growth to the FSD, too.

East Africa is a Sub-Saharan Africa region with significant problems on the one hand and great potential for sustained economic growth on the other hand. There are a number challenges to further development. Persistent poverty, low level of human development, non-inclusive growth, lack of infrastructures and weaknesses in governance are among others.The Sub-Saharan FSD in general and the East African in particular, is very infant one because there are almost no financial markets in the region.

The objective of this study is mainly an attempt to verify the effect and contribution of the FSD to the dynamic Economic Growth and vice versa using dynamic panel FMOLS under Cointegration environment. We provide a number of related empirical literature studies; description of the variables; specification and estimation of the models that inspire the study in genuine options concerning methods for the analyses.

Several studies have been trying to explain the complementarity between the financial sector and economic growth, despite the fact that the existence of the issue is quite sure known for many years. The theoretical explanations in the literature provide the FSD- led Economic Growth Hypothesis or the Growth-led FSD Hypothesis. This study adds an important unique contribution to the existing stock of knowledge about the analyses of FSD-real GDP model. Since it provides the econometric application with dynamic variance decomposition and response function of the FSD to Economic Growth and vice versa, in addition to dynamically estimates the short-run and long-run parameters and tests in a panel. As far as we know, there is no study attempts to look into this kind of dual inter-temporal causal relationship between Financial Sector Development and Economic Growth with dynamic FMOLS model.

Therefore, extensively study of the Financial Sector Development FSD contribution to Economic Growth and the debates on inter-temporal causal relationship motivate me to study whether there is a finance-led growth or a growth-led finance response for the East African Economic Growth. That is, we claim both the supply and demand sides' hypotheses for the empirical analyse to be made. Explicitly, we have made a scientific hypothesis of justification that the stronger financial sector governed by comprehensive Expansionary Monetary Policy, the greater opportunity for the economy to be everlastingly growth and the dynamic economy accelerates the FSD development.

The paper is structured as follows: the next section highlights surveys of the related literature reviews; section three describes the data and methodology used. In section four, discussion and empirical findings are provided and finally, the main findings of the study are summarized in concluding section. 


\section{Related Literature Reviews}

Many empirical studies have indicated finance and economic growth are interrelated, for instance, (Adusei, 2013) study on Finance-Growth Nexus; (Agnieszka, 2013) Financial Liberalization, Development, Productivity and Growth; (Anthony and Tajudeen, 2010) Financial Development and Economic Growth; (Beck et al.1999) Finance and the Sources of Growth; (DFID,2004) the Importance of Financial Sector Development for Growth and Poverty Reduction; (Frank and Eric 2012) Financial Sector Deepening and Economic Growth in Ghana; (Jones,2009) Financial Development and Economic Growth: Evidence from South Africa; (Kessy,2011) the Role of Financial Sector Reforms on Development and Growth of Microfinance Sector;( Levine and Zervos, 1996) Stock Market Development and Long-run Growth; (Levine, 1997) Financial Development and Economic Growth; (Levine, 1997) Finance and Growth; (Mankiw et al., 1992) a Contribution to the Empirics of Economic Growth and (Martin, 1996) Financial Repression and Financial Reform in Uganda and (Najia, 2013) studies the Impact of Development and Efficiency of Financial Sector on Economic Growth: Empirical Evidence from Developing Countries are among others.

Empirically, studies by (Levine and Zervos, 1998 and King and Levine 1993) deeply see the role and contribution of the financial sector in economic development in cross-countries analysis, indicating stock market liquidity and banking sector development have a positive correlation with economic growth in both short run and long run period in most countries. Nevertheless, regarding an important contribution of financial sector development to economic growth, a number of controversial empirical studies have described the issue extensively. Evidences from recent empirical studies suggest that deeper, broader and better functioning of the FSD can stimulate economic growth of a given country, for example (United Nations Economic and Social Council Economic Commission for Africa and African Union (2014) overview of recent economic and social developments in Africa; World Economic Forum (2012) and World Economic Outlook (2015) point out the importance of Financial Sector Development.

From individual point of views, some scholars such as (Stern, 1989; Sofia et.al. 2011; Ugbaje and Edez, 2014; Montfort, et.al. ,2013; Najia, 2013; Adusei, 2013; Wampa,2013; Wafaa et.al., 2013;Frank and Eric,2012; Anthony and Tajudeen, 2010; Jones, 2009; Paul,2004;Ndikumana ,2001;Levine,1997; Levine and Zervos ,1996 and Pagano, 1993) try to see the importance of finance for the development. While others like Athenia and Alfred (2014), Agnieszka (2013), Ndlovu (2013), Ali (2012) and Nicholas (2008), Rym et al.(2013) argue that financial development is unidirectional causality from economic growth to financial development. On the other hand, (Hshin-Yu and Reichert, 2006) show mixed results, for example, some scholars indicate a negative relationship between the financial sector development and economic growth (see the analyses made by (Cecchetti and Kharroubi, 2015 and Rym et al.2013)). However, (Lucas, 1988 and Stern 1989) suggest that there is no relationship between financial sector development and economic growth. For Lucas (1988), finance is an 'over- stressed' determinant of economic growth.

\section{Data Sources and Methodology}

The methodological foundation of this study is (Baltagi, 2005) Econometric Analysis of Panel Data. The Panel Data Econometric analyses approach used by (Baltagi, 2006) on Panel Data Econometrics-Theoretical Contributions and Empirical Applications; (Hahn ,1999) how Informative is the Initial Condition in the Dynamic Panel Model with Fixed Effects; the study of (Blundell and Bond, 1998) on Initial Conditions and Moment Restrictions in Dynamic Panel Data Models; (Ahn and Schmidt, 1995) for Efficient Estimation of Models for Dynamic Panel Data; and (Islam, 1995) Growth Empirics from a Panel Data Approach ; dynamic demand for natural gas in (Baltagi and Levine, 1986); dynamic wage equation of (Arellano and Bond, 1991) and a dynamic model of company investment in (Islam, 1995) are the most top studies among others. The dynamic panel data models continue to exhibit the growth phenomenal. This means most of economic models are either implicitly or explicitly dynamic in nature (Baltagi, 2005). Within this kind of methodology, we gather the appropriate and reliable data for the effective analyses.

\subsection{Data Sources}

The panel data of nine East African countries over the period 1975-2014 are used and analysed. The annual data are obtained from the United Nations Aggregates Databases and World Development Indicators WDI of the World Bank. These data are the primary databases for data development from officially recognized international sources.

\subsection{Measuring Financial Sector}

A good measurement of financial development is crucial in evaluating the progress of financial sector development and understanding the corresponding impact on economic growth (DFID, 2004). The financial sector is the set of institutions, instruments, and the regulatory framework that permit transactions to be made by incurring and settling debts; that is, by extending credit. However, in practice, it is difficult to measure financial development given the complexity and dimensions it encompasses. Since the financial sector of a country comprises a variety of financial institutions, markets and products, this measure only serve as a rough estimate and does not fully capture all aspects of financial development. 
It is a very tough task for setting suitable indicators for measuring the financial sector development. However, many alternative indicators have been suggested in various studies related to the financial development and economic growth. Three indicators are recommended. The first indicator is the Ratio of M2 minus currency in circulation to Nominal GDP used as an indicator of banking sector development (Levine, 1997 and Sofia et al. 2011). The second one is the ratio of domestic credit to private sector to nominal GDP. This indicator measures the quality and quantity of the investment financed by the banking sector. Many researchers use this indicator as a proxy for financial sector development (see: King and Levine, 1993). Third indicator is the assets with the central bank to GDP ratio. Average market capitalization to GDP ratio is used as the indicator of development of stock exchange market. Thus, the ratio of total value of stock market over the nominal GDP shows the financial and investment policy behaviour (Beck et al. 1999).

Unlike all indicators mentioned above, we use the ratio of total Domestic Credit to real Gross Domestic Product as a proxy for the financial Sector Development FSD in this study. This is because; the nominal GDP is subject to inflation, M2 minus Currency in economic circulation results in extensive use of liquid currency outside the banking system, further this also subject to inflation as a large amount of money is not controlled under monetary authority. We don't also consider the ratio of domestic credit to private sector to nominal GDP due to the fact that, its limit in coverage. Credit provided to government and to other sectors would be incorporated. Finally, we also do not consider the ratio of total value of stock market over the nominal GDP as an indicator since there is almost no Stock Market in developing economies in general and in the East African in particular.

A solid and well-functional financial intermediation is an engine powerful behind economic growth. Therefore, the real GDP at 2005 constant price US $\$$ is determined by the ratio of total Domestic Credit to real Gross Domestic Product as a proxy for Financial Sector Development FSD, Gross Capital Formation, net Official Development Assistance and Aid Received from abroad and Official Exchange for a panel of nine East Africa countries including Burundi, Ethiopia, Kenya, Madagascar, Malawi, Mauritius, Rwanda, Uganda and Zambia.

\subsection{Specifications of Dynamic Panel Econometric Model}

The dynamic panel estimators based on the use of lagged observations of the explanatory variables are designed to address the problem of unobserved country specific effects and joint endogeneity of the explanatory variables. In the dynamic panel estimators, we apply the differenced equation to remove any bias created by unobserved country-specific effects and potential parameters inconsistency arising from simultaneity bias, see the studies in (Easterly, 1997; Arellano and Bond, 1991). In the case where the cross sectional dimension are relatively small and the time dimension is large, standard time series techniques is applied to systems of equations and the panel aspect of the data should not pose new technical difficulties (Breitung and Pesaram, 2005).

In terms of applications as (Baltagi, 2005) points out, panel data has an advantageous over pure time series or cross-section data in such a way it controls for individual heterogeneities or differences; it gives more informative, variability, degrees of freedom and efficiency with less collinearity among the variables and it is better able to study the dynamics of adjustment. In addition, panel data is better able to identify and measure effects that are simply not detectable in pure cross-section or pure time-series data. It allows us to construct and test more complicated behavioural models than purely cross-section or time-series data.

Most empirical growth models estimated using panel data are based on the hypothesis of conditional convergence, containing some dynamics lagged variables in the regressors (Islam, 1995).The long-run estimation of dynamic panel econometric models explain macroeconomic events by specifying preferences, technology and institutions and predicts what is actually produced, traded and consumed and how these variables respond to various shocks (William, 2010).

Consider linear dynamic panel data involving lagged dependent variable specification is given by

$$
Y_{i t}=\sum_{j=1}^{p} p_{j} Y_{i, t-j}+X_{i t}^{\prime} \beta+\delta_{i t}+\varepsilon_{i t}
$$

The dynamic panel described in eq. (1) is characterized by two sources of persistence over time. These are autocorrelation due to the presence of a lagged dependent variable among the regressors and the individual effects characterizing the heterogeneity among the individuals. Thus, we cannot apply the ordinary least squares OLS, generalized least squares GLS, Fixed and Random effects methods because $Y_{i t-1}$ is correlated with $\delta_{i t}$ and samples mean of $Y_{i t-1}$ is correlated with that of $\varepsilon_{i t}$ so that the results will be inconsistent (Baltagi, 2005).

First- differencing eq.(1) specification eliminates the individual effects and produces an equation in the form of 


$$
\Delta \mathrm{Y}_{\mathrm{it}}=\sum_{\mathrm{j}=1}^{\mathrm{p}} \mathrm{p}_{\mathrm{j}} \Delta \mathrm{Y}_{\mathrm{i}, \mathrm{t}-\mathrm{j}}+\Delta \mathrm{X}_{\mathrm{it}}^{\prime} \beta+\Delta \varepsilon_{\mathrm{it}}
$$

Phillips and Hansen (1990) propose a fully modified ordinary least squares FMOLS and Pedroni(2000) and Mark and Sul (2003) improve and apply for estimator which employs a semi-parametric to eliminate the problem caused by the long-run correlation between the cointegrating equation and the stochastic regressor innovations. It is asymptotically unbiased which directly comes from the differenced regressions given as

$$
\Delta \mathrm{X}_{\mathrm{it}}^{\prime}=\hat{\Gamma}_{21}^{\prime} \Delta \mathrm{D}_{1 \mathrm{t}}+\hat{\Gamma}_{22}^{\prime} \Delta \mathrm{D}_{2 \mathrm{t}}+\Delta \hat{\mathrm{u}}_{\mathrm{it}}
$$

According to the study by Phillips and Hansen (1990), fully modified ordinary lest squares FMOLS estimator is given by

$$
\widehat{\beta}_{\mathrm{FMOLS}}=\left(\sum_{\mathrm{t}=1}^{\mathrm{T}} \mathrm{Z}_{\mathrm{it}} \mathrm{Z}_{\mathrm{it}}^{\prime}\right)^{-1}\left(\sum_{\mathrm{t}=1}^{\mathrm{T}} \mathrm{Z}_{\mathrm{it}} \mathrm{Y}_{\mathrm{it}}^{*}-\mathrm{T}\left[\begin{array}{c}
\hat{\lambda}_{12}^{*} \\
0
\end{array}\right]\right)
$$

Where $Z_{i t}=\left(X_{i t}^{\prime}, D_{i t}^{\prime}\right)^{\prime}$, the modified data $Y_{i t}^{*}=\widehat{Y}_{i t}-\widehat{\omega}_{12} \widehat{\Omega}_{22} \hat{\mathrm{u}}_{2}$ and estimated biased correction term $\hat{\lambda}_{12}^{*}=\hat{\lambda}_{12}-$ $\widehat{\omega}_{12} \widehat{\Omega}_{22} \widehat{\Lambda}_{22}$. Assume that $\widehat{\Omega}_{22}$ and $\widehat{\Lambda}_{22}$ be the construction of long-run covariance matrix estimators using $\hat{u}_{i t}=$ $\left(\hat{\mathrm{u}}_{1 \mathrm{i}, \mathrm{t}}, \hat{\mathrm{u}}_{2 \mathrm{i}, \mathrm{t}}\right)$. $\mathrm{D}_{1 \mathrm{t}}$ and $\mathrm{D}_{2 \mathrm{t}}$ are deterministic trend regressors.

The most widely-used and efficient methods of estimation for differenced equation are the Generalized Method of Moments GMM of (Arellano and Bover, 1995) and Fully Modified Ordinary Least Squares FMOLS in (Pedroni, 2000). The GMM system of the form developed and studied by (Arellano and Bover, 1995) and discussed in (Ahn and Schmidt, 1995) and (Hahn, 1999) are not only lagged levels used as instruments for first differences, but lagged first differences are used as instruments for levels, which corresponds to an extra set of moment conditions. This method, requires large number of time variable sets, but loses a time-series observation (Hansen, 2013 and 1991). In this study, therefore, we employ FMOLS to estimate a panel cointegrating vector that characterizes the short run and long-run relationship among the variables.

\section{Discussions and Empirical Findings}

The lag-length determination is the key point in the process of testing and estimation variables. The kaike information and other criteria are often used to choose the optimal lag length distributed-lag models. To estimate the lag length, we compute the log-likelihood function and various information criteria for each choice are used (Johansen, 1988, 1991 and 1995).

There are three distinct situations that automatically lag length parameters can be computed. The first situation occurs when we select the lag length parameter for the kernel- based estimators of using (Newey and West, 1994) data-based automatic methods. The other two situations are when the unit root test requires estimation of a regression with a parametric correction for serial correlation as in the augmented Dickey -Fuller ADF and Dickey-Fuller generalized least squares DFGLS test equation regressions and the autoregressive AR spectral estimator. The log-likelihood cannot decrease when additional regressors are included.

Table 4.1 Lag Order Selection using different types of Criteria

\begin{tabular}{ccccc}
\hline Lag & LogL & LR & FPE & AIC \\
\hline 0 & -380.441 & NA & $7.95 \mathrm{e}-06$ & 2.4472 \\
1 & 1701.27 & 4084.12 & $1.70 \mathrm{e}-11$ & -10.611 \\
2 & 1734.75 & $64.620^{*}$ & $1.61 \mathrm{e}-11^{*}$ & $-10.665^{*}$ \\
3 & 1745.816 & 21.008 & $1.76 \mathrm{e}-11$ & -10.576 \\
\hline
\end{tabular}

*indicates by lag selection order criteria of LR: sequential modified LR test statistic, Final prediction error FPE and AIC: Akaike information criterion, the optimal lag length is two at $5 \%$ level.

The result from the test for the lag length, based on the five-variable vector error correction VEC system with the optimum lag length of two, which is reported in Table 4.1. The lag orders chosen by the sequential modified test, Final prediction error, and the Akaike information criteria have shown the optimal lag length is two at 5\% level of significance. The optimum lag length determination is the lowest value of each criterion assumes the most appropriate model. Thus, this lag length two will be used for the rest of analyses throughout the paper. Based on the optimal lag length now can test for Unit Roots. 
Recent literature suggests that panel-based unit root tests have higher power than unit root tests based on individual time series (Baltagi, 2005). A number of panel unit root tests that allow for cross-section dependence use orthogonalization type of procedures to asymptotically eliminate the cross-dependence of the series before standard panel unit root tests are applied. There are two natural assumptions one can assume the persistence parameters are common unit root process that is identical across cross-sections, which includes Levin, Lin, and Chu and Breitung tests whereas the alternative one is to vary freely across cross-sections. The Im, Pesaran, and Shin, Fisher-ADF and Fisher-PP tests allow for individual unit root processes. One major source of cross-section correlation in macroeconomic data is common shocks, such as oil price shocks and international financial crises (Baltagi, 2005). The cross-sectional dependence is a direct descendant of the cross-country on growth according to the study by (King and Levine, 1993; Levine and Zervos, 1998 and Hurlin and Mignon, 2007).

The null hypothesis is a non-stationary behaviour of the time series, admitting the possibility that error terms are serially correlated with different serial correlation coefficients in cross-sectional units (Pesaran, 2007). We determine each variable has a unit root in the presence of cross-sectional dependence across the panel and we report the results in Table 4.2.

Table 4.2 Test for Unit Root in the Presence of Cross-section Dependence

\begin{tabular}{|c|c|c|c|c|c|c|}
\hline \multirow[t]{2}{*}{ Variable } & \multicolumn{2}{|c|}{ Im- Pesaran \&Shin } & \multicolumn{2}{|c|}{ Fisher $\chi^{2}$} & \multicolumn{2}{|c|}{ Fisher ADF PP } \\
\hline & Level & 1st Diff. & Level & 1st Diff. & Level & 1st Diff. \\
\hline \multirow[t]{2}{*}{$\operatorname{lnGDP} P_{\text {it }}$} & 2.19706 & -4.16781 & 18.4764 & 56.6891 & 15.2088 & 104.023 \\
\hline & $(0.9860)$ & $(0.0000)^{*}$ & $(0.4247)$ & $(0.0000)^{*}$ & $(0.6476)$ & $(0.0000)^{*}$ \\
\hline \multirow[t]{2}{*}{$\mathrm{FS}_{\text {it }}$} & 1.54441 & -9.00403 & 11.6111 & 107.489 & 11.1096 & 193.959 \\
\hline & $(0.9388)$ & $(0.0000)^{*}$ & $(0.8666)$ & $(0.0000)^{*}$ & $(0.8896)$ & $(0.0000)^{*}$ \\
\hline \multirow[t]{2}{*}{$\operatorname{lnGCF}_{\text {it }}$} & 0.83003 & -8.96295 & 12.4165 & 105.245 & 18.6104 & 223.307 \\
\hline & $(0.7967)$ & $(0.0000)^{*}$ & $(0.8250)$ & $(0.0000)^{*}$ & $(0.4162)$ & $(0.0000)^{*}$ \\
\hline \multirow[t]{2}{*}{$\operatorname{lnDA} A_{i t}$} & 0.02876 & -7.69269 & 20.9716 & 101.035 & 24.9586 & 254.686 \\
\hline & $(0.5115)$ & $(0.0000)^{*}$ & $(0.2808)$ & $(0.0000)^{*}$ & $(0.1261)$ & $(0.0000)^{*}$ \\
\hline \multirow[t]{2}{*}{$\mathrm{OER}_{\mathrm{it}}$} & 1.11016 & -6.85127 & 12.3629 & 78.8925 & 6.67812 & 100.603 \\
\hline & $(0.8665)$ & $(0.0000)^{*}$ & $(0.8279)$ & $(0.0000)^{*}$ & $(0.9926)$ & $(0.0000)^{*}$ \\
\hline
\end{tabular}

The test includes Individual Intercept \& Trend. User-specified lags: 1 . The null hypothesis assumes individual unit root process and * denotes rejection of the hypothesis at $1 \%$ level of significance.

However, we have to make our data become cross-sectional independence before estimation. Since estimation in the presences of cross-sectional dependence causes bias and inconsistency as Andrew (2005) argues. A standard augmented Dickey-Fuller ADF regression is considered with the cross-section averages of lagged levels and first-differences of the individual series Pesaran(2007) is used for cross sectional dependence test. The limiting distribution of this test is different from the Dickey-Fuller distribution due to the presence of the cross-sectional of the lagged level in which Pesaran(2007) uses a truncated version of the Im,Pesaran Shin test, avoiding the problem of moment calculation Baltagi(2005). Therefore, we conduct the tests for both t-statistic and Pesaran Cross-section Dependence and confirm there is no Cross-sectional Dependence in each series after transformation of the original data through demeaned method (the method is available in Walter (2004)., i.e., the difference between the individual observation and the common average of the series in which the tests outputs are reported in Table 4.3.

Table 4.3 Test for cross-sectional Independence for Demeaned Data series

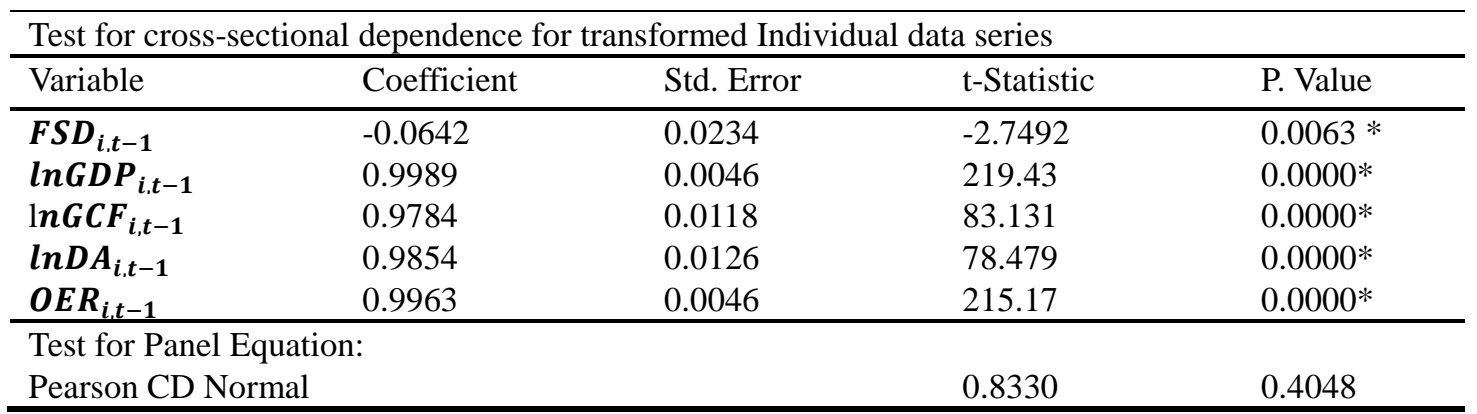

* refer to the rejection of the null hypothesis of Cross-sectional Independence at $1 \%$ level of significance using t-statistic for the test, while of the null hypothesis of Cross-sectional independence for a panel equation is not rejected. $\operatorname{lnGDP} \mathrm{i}_{\mathrm{i}, \mathrm{t}}$ denotes GDP in log form. 


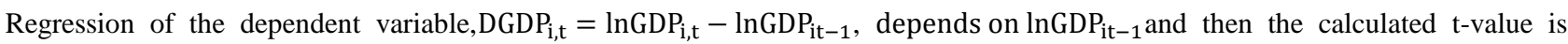
considered for the hypothesis of cross-sectional dependence of individual transformed data series.

We take into account about panel cointegration methodology developed by (Johansen, 1988); later on applied by (Saikonen, 1992) for estimation and testing of Cointegrating Systems in Autoregressive Approximation and (Stock-Watson, 1993) use for a Simple Estimator of Cointegrating Vectors in Higher Order Integrated Systems and (Johansen 1995) highlight about solving the problem of eigenvalues and finally, inferences that can be conducted the test hypothesis for long-run relationship. Like panel unit root tests, panel cointegration tests can be motivated for its more powerful tests than individual time series cointegration tests. In the case of purchasing power parity and convergence in growth, economists use pool data on similar countries, in the hopes of adding cross-sectional variation to the data will increase the power of panel cointegration tests (Baltagi, 2005).

In order to test the long run relationship among a five panel series in multivariate analyses, we use the Johansen approach. Table 4.4 shows the Johansen Test for Unrestricted Rank and number of Cointegration equation when Financial Sector Development is a dependent variable. Both the Trace and the Maximum eigenvalue tests in the first column of the table indicate number of cointegrating vectors, which are the hypotheses of the variables not cointegrated $(r=0)$ against the alternative of one or more cointegrating vectors $(r>0)$. Since the values of Trace Statistic (0) and Maximum Eigen Statistic(0) exceed their respective the critical values at the $5 \%$ significance level, we reject the null hypothesis of zero cointegrating vectors $(\mathrm{r}=0)$ and accept the alternative hypothesis of more than zero cointegrating vectors ( $r>0)$. On the other hand, the values of Trace Statistic (1) and Maximum Eigen Statistic (1) are less than their respective the critical values at the $5 \%$ significance level, we don't reject the null hypothesis of $r \leq 1$ cointegrating vectors ( $r=1)$ and reject the alternative hypothesis of more than one cointegrating vectors $(r>0)$. This suggests the Johansen test gives number of cointegration vector is one within five series. More explicitly, we don't reject the null hypothesis at $5 \%$ level of significance that there is one cointegrating equation since the critical values in Trace statistic and Maximum eigenvalue less than the their respective critical values. Hence, the variables are integrated of the same order and they move together towards the long run equilibrium or have a long run relationship. When real GDP is considered as dependent, the test output also displays the same number of cointegrating equation, which has been accessed from the author.

Table 4.4 Johansen Test for Unrestricted Rank(r) and No. of Cointegration Equation

\begin{tabular}{llllllll}
\hline Hypothes & \multicolumn{2}{l}{ Trace test } & & \multicolumn{3}{l}{ Maximum Eigenvalue test } \\
\cline { 2 - 7 } No of CE & $\begin{array}{l}\text { Eigen } \\
\text { value }\end{array}$ & Trace St & $5 \%$ Critic & P. Value & $\begin{array}{l}\text { Max. Eigen } \\
\text { Statistic }\end{array}$ & 5\%Critical & P. Value \\
\hline None & 0.1212 & 80.408 & 69.819 & $0.0056^{*}$ & 40.703 & 33.877 & $0.0066^{*}$ \\
At most 1 & 0.0606 & 39.706 & 47.856 & 0.2332 & 19.706 & 27.584 & 0.3618 \\
At most 2 & 0.0445 & 19.999 & 29.797 & 0.4229 & 14.347 & 21.132 & 0.3372 \\
At most 3 & 0.0163 & 5.6522 & 15.495 & 0.7362 & 5.1633 & 14.265 & 0.7211 \\
At most 4 & 0.0016 & 0.4889 & 3.8415 & 0.4844 & 0.4889 & 3.8415 & 0.4844 \\
\hline
\end{tabular}

Both Trace and Max-eigenvalue tests indicate there is one cointegrating equation. * denotes rejection of the hypothesis at the $5 \%$ level of significance. The trend assumption is linear deterministic with lag interval (in the first differences) is 1 to 2.

Since the number of cointegration within the five series is confirmed, we continue to the next step of estimation of the short-run and long-run parameters. The analysis of long-run cointegrating relationships has received a considerable attention by a number of researchers such as (Pablo, 2010) in Dynamic OLS Estimation; (Pedroni, 2000; Mark and Sul, 2003) about Fully Modified OLS estimators and (Barro, 1998) focuses on determinants of Economic Growth a case where a cross-country empirical results are in asymptotically unbiased. However, we encounter with the endogeneity problem due to simultaneous equations of the real GDP-FSD model. In the presence of endogeneity, estimations become bias and inconsistent. Therefore, we have to provide a solution with the help of instrumental variables IVs and two stages least squares 2SLS (see detailed: Wooldridge, 2002, 1997a) for the endogeneity.

Consider the following simultaneous equations of GDP-FSD model where lnGDP and FSD are endogenous variables whereas $\operatorname{lnGCF}, \operatorname{lnDA}$ and OER are predetermined.

$$
\begin{gathered}
\ln G D P=\beta_{0}+\beta_{1} F S D+\beta_{2} \ln G C F+\beta_{3} \ln D A+u \\
F S D=\beta_{10}+\beta_{11} \ln G D P+\beta_{12} O E R+v
\end{gathered}
$$


Here, we apply the methods of instrumental variables IVs and two stages least squares 2SLS for endogeneity arises from simultaneous equations model, before estimating the dynamic panel of long-run coefficients using FMOLS.

Where $\ln G C F$ and $\ln D A$ are not correlated with $u, \operatorname{Cov}(\ln G C F, u)=0 \operatorname{Cov}(\ln D A, u)=0$ and $\operatorname{Cov}(F S, u) \neq 0$, $\operatorname{Cov}(F S, O X R) \neq 0$ and $\operatorname{Cov}(O X R, u)=0$. Thus, $O E R$ can be used as instrumental variable IV for FS in eq(4a). Similarly, in eq(4b), lnGCF and lnDA are IVs for lnGDP, however, the solution is not unique, which depends on whether lnGCF or lnDA since the FS function is over-identified whereas lnGDP is exact - identified.

Under instrumental variables, we have to run FSD on $\operatorname{lnGCF}, \operatorname{lnDA}$ and OXR using OLS and obtain the estimated value of FSD-OSL. Then we estimate the real GDP using dynamic panel FMOLS by taking lnGDP as a dependent and the estimated FSD-OSL, lnGCF and lnDA as explanatory variables. Lastly, we regress $\ln$ GDP on $\operatorname{lnGCF}$ and OER as $\operatorname{lnGCF}$ is an IV-one for $\operatorname{lnGDP}$ or $\operatorname{lnGDP}$ on $\operatorname{lnDA}$ and OER as $\operatorname{lnDA}$ is another IV for $\operatorname{lnGDP}$. However, these lead us to a nonunique solution, which depends on whether $\operatorname{lnGCF}$ or $\operatorname{lnDA}$ is considered as an IV for $\operatorname{lnGDP}$. To estimate the FSD equation by FMOLS method, we consider the larger value of coefficient of determination between these two regressions.

The two stages least squares 2SLS is also applied for solving the problem of endogeneity arises from simultaneous equations model as eq(4a) is exact-identification and eq(4b) is over-identification. We first estimate the reduced form equations by OLS; that is, regress FS on $1 \mathrm{nGCF}$, InDA and OER by OLS and obtain the estimated FSD-OSL, then we estimate $\operatorname{lnGDP}$ as a function of estimated FSD, $\operatorname{lnGCF}$ and $\operatorname{lnDA}$ by FMOLS in eq.(4a). Likewise, for eq.(4b), we regress $\operatorname{lnGDP}$ on $\operatorname{lnGCF}, \operatorname{lnDA}$ and OXR using OLS and obtain the estimated lnGDP, then replace lnGDP by the estimated lnGDP and estimate FSD as a function of the estimated lnGDP and OER by FMOLS. The main difference between IVs and 2SLS is that in the former case the estimated value of the variables are used as instruments, while in the latter case they are used as regressors, in the case where there is exactly-identification, the results of IVs and 2SLS are the same.

Note that $\widehat{F S D}$-OLS, $\widehat{F S D}$-2SLS, $\ln \widehat{G D P}$-2SLS, lnGDP-2SLS denote the estimated Financial Sector Development FSD and real lnGDP by -OLS and -2SLS methods, respectively.

Table 4.5 Dynamic Panel FMOLS Estimation of Long-run Coefficients 19752014

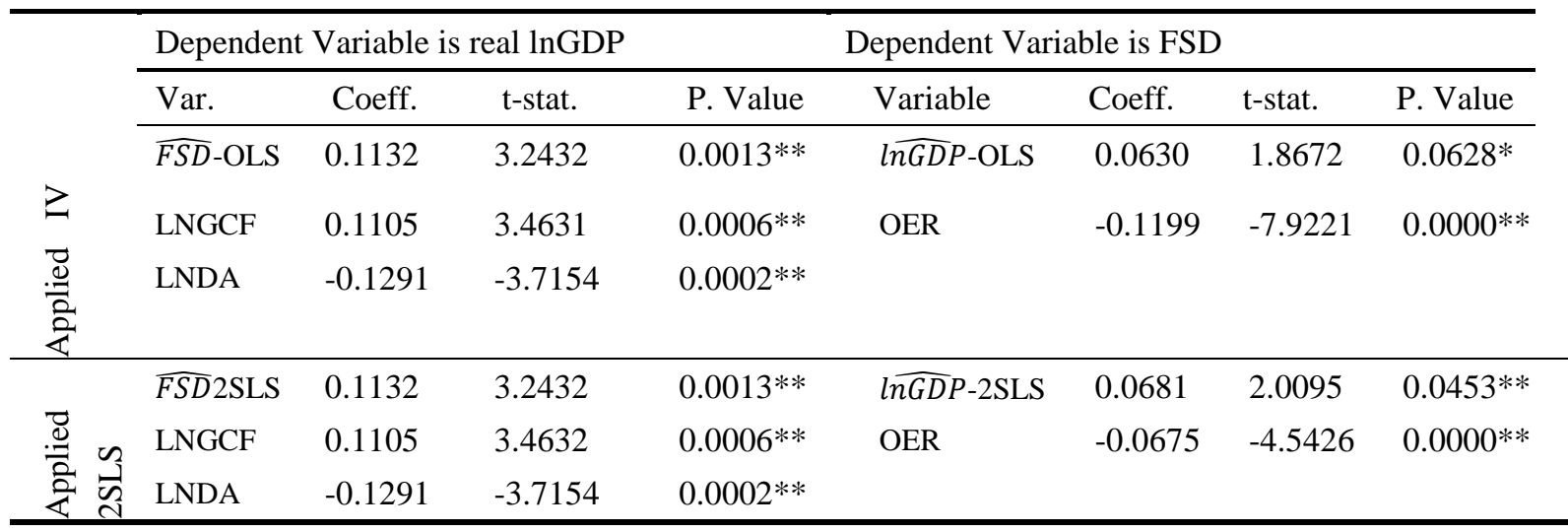

** and * denote the level of significance at $5 \%$ and $10 \%$ with the optimal lag length is two. Cointegration equation deterministic includes constant and trend. Regressor equations estimated using differences in the method of Weighed Panel Estimation first -stage residuals heterogeneous long-run coefficients.

After model diagnostic testing for the residual normality distribution and non-serial correlation (the tests outputs have been accessed from the author), the long-run estimations are reported in Table 4.5. The estimated FSD (by the IVs and 2SLS) and Gross Capital Formation GCF have positively significant contribution to the Economic Growth lnGDP. This means, a one percentage point increases in the estimated FSD increases the realGDP(in log form) by 11.32 percentage and a unit increases in GFC that increases the real GDP by 11.05. While the net Official Development Assistance and Aid received from abroad $\ln \mathrm{DA}$ has negatively significant impact on the East African Economic Growth over the period 1975- 2014. The negative effect of lnDA on the real lnGDP may be people become dependent on the assistance and reluctant to work, hence productivity decline eventually falling in real lnGDP. On the other hand, the estimated real lnGDP by the IVs and the 2SLS has a positive significant role for the development of Financial Sector FSD; however, the Official Exchange Rate OER has significantly negative effect.

Negative impact of OER may be due to that fact, high currency depreciation in a sample countries study. Evidences confirm concerning about negative effect of the official exchange rate OER on the FSD performance are (Gerardo and Felipe, 2002) describes the G-3 exchange rate volatility and evaluates its impact on developing countries, empirically shows a robust and significantly negative impact on developing countries' exports and (Hua, 2011) estimates the 29 Chinese provinces panel data over the period from 1987 to 2008, using the GMM system estimation and the results shows the real exchange rate appreciation had a negative effect on the economic growth and employment. Furthermore, 
(Kandil, 2004) examines the effects of exchange rate fluctuations on real output growth and price inflation in a sample of twenty-two developing countries and concludes the exchange rate depreciation, decreases real output growth. Likewise, a negative relationship of lnDA with real GDP is confirmed in studies by (Ekanayake and Chatrna 2008) in which findings indicate, foreign aid has mixed effects on economic growth analyse of 85 developing countries for the period 1980-2007 and (Vanarith, 2009) shows aid has no positive effect on economic growth. However, it is positively related to corruption in 67 developing countries from 1986-2005 using panel data. Though, the United Nations Millennium Development Goals Declaration explicitly recognized the role of Official Development Assistance in the development process, committed industrialized countries to "grant more generous development assistance" (UN, 2000).

Table 4.6 VEC Granger Causality/Block Exogeneity Wald Tests

\begin{tabular}{llrl}
\hline Dependent variable & Independent Variable & $\chi^{2}$ & P. Value \\
\hline Estimated FSD -2SLS & Estimated lnGDP -2SLS & 5.2215 & $0.0735^{*}$ \\
& & & \\
Estimated lnGDP -2SLS & Estimated FSD -2SLS & 8.9627 & $0.0379^{* *}$ \\
\hline
\end{tabular}

$* *$ and $*$ denote the level of significance at $5 \%$ and $10 \%$ with the optimal lag length of two.

We also conduct a vector error correction VEC Granger Causality tests between estimated FSD and estimated real GDP to show a directional causation for a panel countries study. There is a bi-directional cause from the GDP to the FSD, and vice versa (see Table 4.6). However, this test doesn't explicitly indicate the change in magnitude. Thus, we have to look for the Variance-Response function analyses under the Panel Cointegration.

Table 4.7 Variance Decomposition and Impulse Response of Estimated FSD and GDP

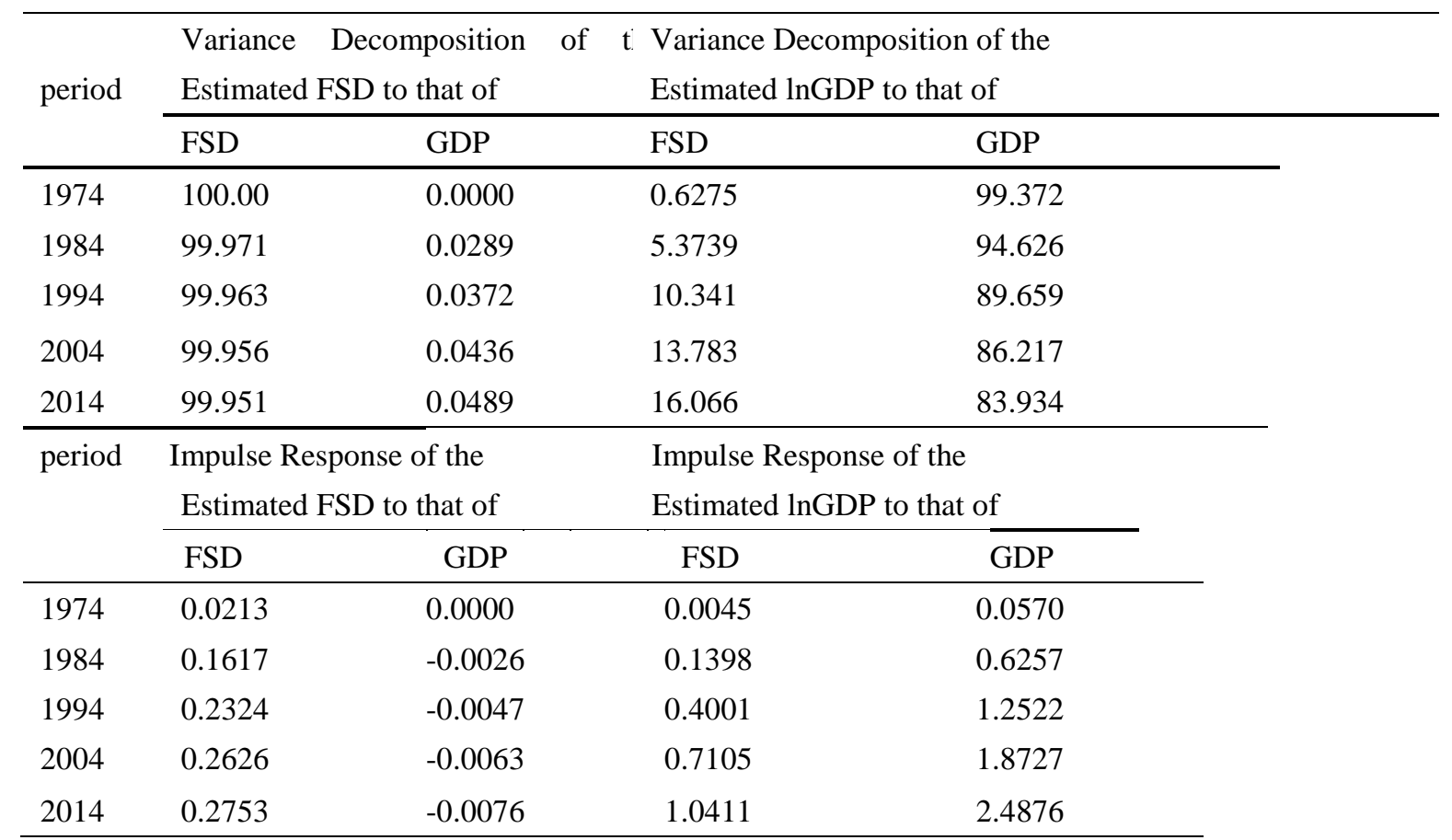

Cholesky Ordering: DCPGDP, lnGDP and Standard Errors is Monte Carlo (1000000 repetitions). DCPGDP and lnGDP represents financial sector FS and GDP, respectively. Here in the cointegration environment, it is possible to find out the Variance Decomposition and Impulse Response Functions using (1,000,000 times of Monte Carlo Repletion).

Table 4.7 shows impulse innovation to the estimated Financial Sector FSD and the estimated GDP. The fluctuations of FSD and GDP are mainly explained by GDP shocks and FSD shocks in the long run. The FSD shock accounts for $0.03 \%$ fluctuates in GDP while the real GDP shock accounts for 5.37\% fluctuates in FSD in the year 1984. The proportion in the variance of GDP and FSD slightly decreases over time and reaches $83.93 \%$ and $99.95 \%$ in the year 2014, respectively. For these shocks, the accumulated response of GDP to FSD increases. We can also show graphically the accumulated response of real GDP to the FSD and vice versa in Fig.1, (in Appendix C) on the upper to the right side and bottom to the left side. 
These empirical results are related to the previous studies by (David, 2012 and Susan, 2014). The gain of this study, therefore, provides the supply and demand leading hypotheses by dynamic panel FMOLS, means FSD accelerates and augments the Economic Growth and vice versa.

\section{Concluding Remarks and Implication}

This paper explores the effect and contribution of Financial Sector Development FSD to the East African economic Growth over the period 1975-2014. Regarding an important contribution of FSD to Economic Growth, a number of controversial empirical studies have been described and extensively studied whether the FSD has a positive impact on economic growth, or not. Specifically, the debates on the inter-temporal causal relationship have been targeted to study whether there is a finance-led growth or a growth-led finance response for the East African economy.

Empirically, the contributions of the FSD and the Gross Capital Formation GCF have positively significant to the Economic Growth. While the net Official Development Assistance and Aid received from abroad lnDA has negatively significant impact on the East African economic Growth over the period 1975 2014. The negative effect of DA on the real GDP may be people become dependent on the assistance and reluctant to work, hence productivity decline eventually falling in real GDP. On the other hand, the estimated real GDP by has a positive significant role for the development of Financial Sector FSD; however, the Official Exchange Rate OER has significantly negative effect. This negative result may be due to that fact high currency depreciation against in a sample of countries study.

A vector error correction VEC Granger Causality test between estimated financial sector and estimated real GDP show that there are two way-directional causes from the GDP to the FSD and the FSD to real GDP. In addition, the proportion in the variance of GDP and FSD slightly decreases over time and reaches $83.93 \%$ and $99.95 \%$ in the year 2014, respectively. For these shocks, the accumulated response of GDP to FS increases.

The gain of this study, therefore, provides the Supply and Demand Leading Hypotheses, means FSD accelerates and augments the Economic Growth and vice versa. The implications drawn from this study are the reforms in the FS; inclusiveness of Financial System and effective vigorously pursued expansionary monetary policy, which directs the economy, could be a comprehensive beneficial to the study countries.

\section{Acknowledgement}

The author would like to thank his supervisors: Borje Johansson, Kristofer Mansson and Sisay Regassa. for the comments on the paper, which is one of the chapters of his $\mathrm{PhD}$ dissertation.

\section{References}

Adusei, M. (2013). Finance-Growth Nexus in Africa: A Panel Generalized Method of Moments (GMM) Analysis. Asian Economic and Financial Review, 3(10),1314-1324.

Agnieszka, G. (2013). Financial Liberalization, Financial Development and Productivity Growth - An Overview, Economics Discussion Papers, No 2013-46, Kiel Institute for the World Economy.

Ahn, S., \& Schmidt, P. (1995).Efficient Estimation of Models for Dynamic Panel Data. Journal of Econometrics, 68, 5-27.

Ali, A. (2012). Banking Sector Development and Economic Growth in Lebanon, International Research Journal of Finance and Economics ISSN 1450-2887 Issue 100, Euro Journals Publishing, Inc.

Ali, I. A., \& Emerta, A. A. (2012), Financial Sector Development in the IGAD Region, The Horn Economic and Social Policy Institute, Policy paper, 12.

Andrews, D. W. K. (2005).Cross-section regression with common shocks", Econometrica, 73, 1551-1586.

Anthony, E. A., \& Tajudeen, E. (2010). Financial Development and Economic Growth: The Experience of 10 Sub-Saharan African Countries Revisited. The Review of Finance and Banking, 2(1), 17-28.

Arellano, M., \& Bover, O. (1995). Another Look at the Instrumental-Variable Estimation of Error-Components Models, Journal of Econometrics, 68, 29-51. Bagehot.

Athenia, B. S., \& Alfred, B. (2014). Banking sector development and economic growth: Evidence from Zimbabwe, Banks and Bank Systems, 9(2).

Badi, H. B. (2006). Panel Data Econometrics-Theoretical Contributions and Empirical Applications. Department of Economics and Center for Policy Research Syracuse University, Syracuse, NY 13244-1020U.S.A.

Baltagi, H. B. (2005). Econometric Analysis of Panel Data( $3^{\text {rd }}$ Edition). John Wiley\& Sons, Ltd.

Barro, R. J. (1998). Determinants of Economic Growth: A Cross-Country Empirical Study. Journal of Comparative Economics 26, 822-824 Article No. Je981532 
Beck, T., Demirgüç-Kunt, A., \& Levine, R. (1999). A New Database on Financial Development and Structure. World Bank Economic Review, 14, 597-605.

Blundell, R., \& Bond, S. (1998).Initial Conditions and Moment Restrictions in Dynamic Panel Data Models, Journal of Econometrics, 87(1), 115-43.

Breitung, J., \& Pesaran, M. H. (2005). Unit Roots and Cointegration in Panel. CWPE 0535.

David, C. (2012). Policy Innovations to Improve Access to Financial Services in Developing Countries: Learning from Case Studies in Kenya, Centre for Global Development.

Department for International Development, DFID (2004). The Importance of Financial Sector Development for Growth and Poverty Reduction, Policy Division Working Paper, 6-13, London and Glasgow, UK.

Easterly, W., \& Levine, R. (1997).Africa's growth tragedy: policies and ethnic divisions.

Ekanayake, E. M., \& Chatrna, D. (2008).The Effect of Foreign Aid on Economic Growth in Developing countries. Journal of International Business and Cultural Studies

Frank G. S., \& MaricNkrumah, E.(2012). Financial Sector Deepening and Economic Growth in Ghana. Journal of Economics and Sustainable Development ,3(8).

Gerardo, E., \& Felipe, L.B. (2002). The Impact of G-3 Exchange Rate Volatility on Developing Countries. Research papers for the Intergovernmental Group of Twenty-Four on International Monetary Affairs United Nations, G-24 Discussion Paper No. 16, New York.

Getnet, A. (2014). Financial inclusion, regulation and inclusive growth in Ethiopia, Working paper, 408.

Girma, T. (2012). Management of Commercial Banks in Ethiopia from the Perspective of Financial Inclusion, European Journal of Business and Management, 4(3).

Hahn, J., (1999).How Informative Is the Initial Condition in the Dynamic Panel Model with Fixed Effects?, Journal of Econometrics, 93(2), 309-26.

Haile, K., \& James, W. (2014). United Nations Development Program, Ethiopia's Policy Advisory Unit, Country Economic Brief Analysis Issue, 1.

Hansen, B. E. (2013). Econometrics, University of Wisconsin, 298.

Hansen, B. E. (1991). Efficient Estimation and Testing of Cointegrating Vectors in the Presence of Deterministic Trends. Journal of Econometrics, 53, 87-121.

Liang, H. Y., \& Alan, R. (2006). The Relationship between Economic Growth and Banking Sector Development, Banks and Bank Systems, 1(2).

Hua, P. (2011). The economic and social effects of real exchange rate: Evidence from the Chinese provinces International Conference on Social Cohesion and Development. 20-21 January 2011, Paris, France.

Hurlin, C., \& Mignon, V. (2007). Second Generation Panel Unit Root Tests. HAL Id: halshs-00159842.

Islam, N. (1995). Growth Empirics: A Panel Data Approach, Quarterly Journal of Economics, 1127-70.

Johansen, S. (1988). "Statistical Analysis of Cointegration Vectors," Journal of Economic Dynamics and Control, 12(2-3), 231-254.

(1991). Estimation and Hypothesis Testing of Cointegration Vectors in Gaussian Vector Autoregressive Models," Econometrica, 59(6), 1551-1580.

(1995). Likelihood-Based Inference in Cointegrated Vector Autoregressive Models. New York, Oxford University Press.

Jones, G. (2009). Financial Development and Economic Growth: Evidence from South Africa.

Kandil, M. (2004). Exchange Rate Fluctuations and Economic Activity in Developing Countries: Theory and Evidence. International Monetary Fund, Journal of Economic Development, 29(1).

Kessy S. S. A. (2011). The Role Of Financial Sector Reforms On Development And Growth Of Microfinance Sector In Tanzania. Paper Submitted For The Workshop In Campinas, Brazil.

Levine, R., \& Zervos, S. (1996). Stock market development and long-run growth. The World Bank Economic Review 10(2), 323-329.

Levine, R.(1997). Financial Development and Economic Growth: Views and Agenda, Journal of Economic Literature, $X X X V, 688-726$. 
Levine, R.(1999). Finance and Growth: Theory and Evidence, Handbook of Economic Growth, in: Philippe Aghion \& Steven Durlauf (ed.), Handbook of Economic Growth, edition 1, 1(12), 865-934.

Lucas, R. E. (1988). On the mechanics of economic development. Journal of Monetary Economics, 22(1), 3-42.

Mankiw, N. G., Romer, D., \& Weil, D. (1992). A Contribution to the Empirics of Economic Growth. Quarterly Journal of Economics, 107(2), 407-37.

Mark, N. C., \& Sul, D. (2003). Cointegration Vector Estimation by Panel DOLS and Long-run Money Demand. Oxford Bulletin of Economics and Statistics, 65, 305-9049.

Martin, B. (1996). Financial Repression and Financial Reform in Uganda, UNCTAD (Division for Least Developed Countries) in Geneva, Switzerland.

Montfort Mlachila, Nedbank Sabina Zajc, Paul-Harry Aithnard, Dennis Dykes, Thorsten Beck, Mthuli Ncube and Oskar Nelvin (2013). Banking in sub-Saharan Africa: Challenges and Opportunities, European Investment Bank

Najia, S. (2013). Impact of Development and Efficiency of Financial Sector on Economic Growth: Empirical Evidence from Developing Countries, Journal of Knowledge Management, Economics and Information Technology, III(3).

Ndlovu, Godfrey (2013). Financial Sector Development and Economic Growth: Evidence from Zimbabwe. International Journal of Economics and Financial Issues, 3(2), 435-46.

Newey - West (1994).Automatic Lag Selection in Covariance Matrix Estimation.

Nicholas, M. O. (2008). Financial Development in Kenya: a Dynamic Test of the Finance-led Growth Hypothesis, Economic Issues, 13(2).

Pablo Camacho-Gutierrez (2010). Dynamic OLS estimation of the U.S. import demand for Mexican crude oil, Texas A \& M International University, U.S.

Pagano, M. (1993). Financial Markets and the Macroeconomy: an overview of Financial markets and growth, European Economic Review, 37, 613-622. North-Holland, Elsevier Science Publishers B.V.

Park, J. Y. (1992). Canonical Cointegrating Regressions, Econometrica, 60, 119-143.

Paul, V. A. (2004). Capital Market and Financial Sector Development in Sub-Saharan Africa: A Report of the Africa Policy Advisory Panel. The Center for Strategic and International Studies (CSIS).

Pedroni, P. (2000). Fully Modified OLS for Heterogeneous Cointegrated Panels Nonstationary Panels, Panel Cointegration and Dynamic Panels, 15, 93-130.

Pesaran, M. H. (2007). A simple panel unit root test in the presence of cross-section dependence. Journal of Applied Econometrics, 22, 265-312.

Phillips, P. C. B., \& Hansen, B. E. (1990). Statistical inference in instrumental variables regression with $I(1)$ processes, Review of Economic Studies, 57, 99-125.

Rym, A., Emrah, A., Ben-Naceur, S., \& Willem, P. De. G. (2013). Financial Development, Bank Efficiency and Economic Growth across the Mediterranean, MEDPRO Technical Report, 3.

Saikonen, P. (1992). Estimation and Testing of Cointegrating Systems by Autoregressive Approximation, Economic Theory, 8, 1-27.

Sofia, A., Ghulam, S., \& Zakir, H. (2011). Relationship between Financial Sector Development \& Sustainable Economic Development: Analysis from Pakistan. International Journal of Economics and Finance, 3(1).

Stern, N. (1989). The Economics of Development: A Survey, Economic Journal, 99(397), 597-685.

Stock, J. H., \& Mark, W. (1993). A Simple Estimator of Cointegrating Vectors in Higher Order Integrated Systems, Econometrica, 61, 783-820.

Susan, M. O. (2014). Financial Development and Economic Growth in Kenya: An Empirical Analysis 1980-2011. International Journal of Economics and Finance, 6(7).

Thorsten, B., \& Samuel, M. M. (2013). Financial Sector Development in Africa: Opportunities and Challenges. International Bank for Reconstruction and Development, The World Bank, Washington, USA.

Ugbaje, D. O., \& Ugbaje, H. E. (2014). Empirical Study of Financial Sector Development on Economic Growth in Nigeria (1990-2010), International Journal of Public Administration and Management Research, 2(3), 122-137.

United Nations Department of Economic and Social Affairs (2010). Development Cooperation for the MDGs Maximising Results, International Development Cooperation Report, UNDESA, New York. 
UNESC and AU, United Nations Economic and Social Council Economic Commission for Africa and African Union (2014). Overview of recent economic and social developments in Africa, the Committee of Experts of the Seventh Joint Annual Meetings, Nigeria, Abuja.

VanarithChheang, B. B. A (2009).The Effect of Foreign Aid on Economic Growth and Corruption in 67 Developing Countries (Unpublished master's thesis). Georgetown University, Washington, D.C.

Wafaa, S. Rafiq, B., \& Hanas, A. C. (2013).The effect of financial sector development on economic growth: Evidence from the GCC Countries, Journal of Business Administration and Management Sciences Research, 2(9), 191-202.

Walter Enders (2004). Applied Econometric time Series( second edition). Wiley Series in Probability and Statistics, Alabama University.

Wampah, H. A. K. (2013). What does it take to build a stable and efficient financial sector for sustaining growth and structural transformation in Africa? Governor of

Whitney K. N., \& Kenneth, D. W. (1994).Automatic Lag Selection in Covariance Matrix Estimation. Reviews of Economic Studies, 61, 631-653.

William J. T. (2010). Why I use Dynamic Stochastic General Equilibrium Models for researching Monetary theory and Policy.

Wolday, A., \& David, P. (2010). Agricultural finance potential in Ethiopia, Constraints and opportunities for enhancing the system, Addis Ababa, Ethiopia.

Wooldridge, J. M. (1997a). Multiplicative Panel Data Models without the Strict Exogeneity Assumption. Econometric Theory, 13, 667-678.

Wooldridge, J. M. (2002).Econometric Analysis of Cross section and Panel Data.The MIT Press Cambridge, Massachusetts, London England.

World Economic Forum (2012). The Financial Development Report, Geneva, Switzerland and New York, USA.

World Economic Outlook (2015). The World Economic Outlook WEO World Economic Studies Division Research Department International Monetary Fund 700 19th Street, N.W. Washington, DC 20431, U.S.A.

$$
\begin{aligned}
& \text { Appendix } \\
& \text { Appendix A- Equation and Its Explanations } \\
& \text { For an } \operatorname{AR}(\rho) \text { error specification, the relevant individual cross sectionally CADF statistics are computed from the } \rho^{\text {th }} \\
& \text { order cross- section/ time series augmented regression is given in Appendix I. } \\
& \qquad \begin{aligned}
\Delta y_{i, t} & =\alpha_{i}+\rho_{i} y_{i, t-1}+c_{i} \bar{y}_{t-1}+\sum_{j=1}^{p} d_{i} \Delta \bar{y}_{t-j} \\
& +\sum_{j=1}^{p} \beta_{i, j} \Delta y_{i, t-1}+\varepsilon_{i, t}
\end{aligned}
\end{aligned}
$$

\section{Appendix A- Equation and Its Explanations}

Where $\varepsilon_{i, t}$ is the idiosyncratic error term, $\bar{y}_{t-1}=\frac{\sum_{i=1}^{N} y_{i, t-1}}{N}$ and $\Delta \bar{y}_{i, t}=\frac{\sum_{i=1}^{N} y_{i, t}}{N}$.

With the transformed data, now we can test for the cross-sectional independence of individual data series (Pesatran, 2004) by constructing a test of null hypothesis $H_{0}: \rho_{i}$ for all $i$, or the alternative one is $H_{a}: \rho_{i}<0$. 


\section{Appendix B- Table}

Table 5.8 Serial Correlation and Normality Tests

\begin{tabular}{|c|c|c|c|c|c|}
\hline \multicolumn{3}{|c|}{$\begin{array}{r}\text { VAR Residual Serial Correlation } \\
\text { LM } \\
\text { Tests }\end{array}$} & \multicolumn{3}{|c|}{$\begin{array}{c}\text { VAR Residual Normality Tests using Cholesky } \\
\text { Orthogonalization }\end{array}$} \\
\hline & & & Distribution & $\chi^{2}$ & P. value \\
\hline Lags & LM-Stat & P. Value & Skewness & 249.68 & $0.0000 *$ \\
\hline 1 & 20.26458 & 0.7328 & Kutrosis & 55843.5 & $0.0000 *$ \\
\hline 2 & 23.32022 & 0.5589 & Jarque-Bera & 56093.2 & $0.0000 *$ \\
\hline
\end{tabular}

* Indicate rejection of the null hypotheses of Serial Correlation at lag order of two and multivariate normality distribution of the residuals in the model.

Appendix C-Graph

Accumulated Response to Cholesky One S.D. Innovations \pm 2 S.E.

Accumulated Response of DEMDCPGDP to DEMDCPGDP

Accumulated Response of DEMDCPGDP to DEMLNGDP
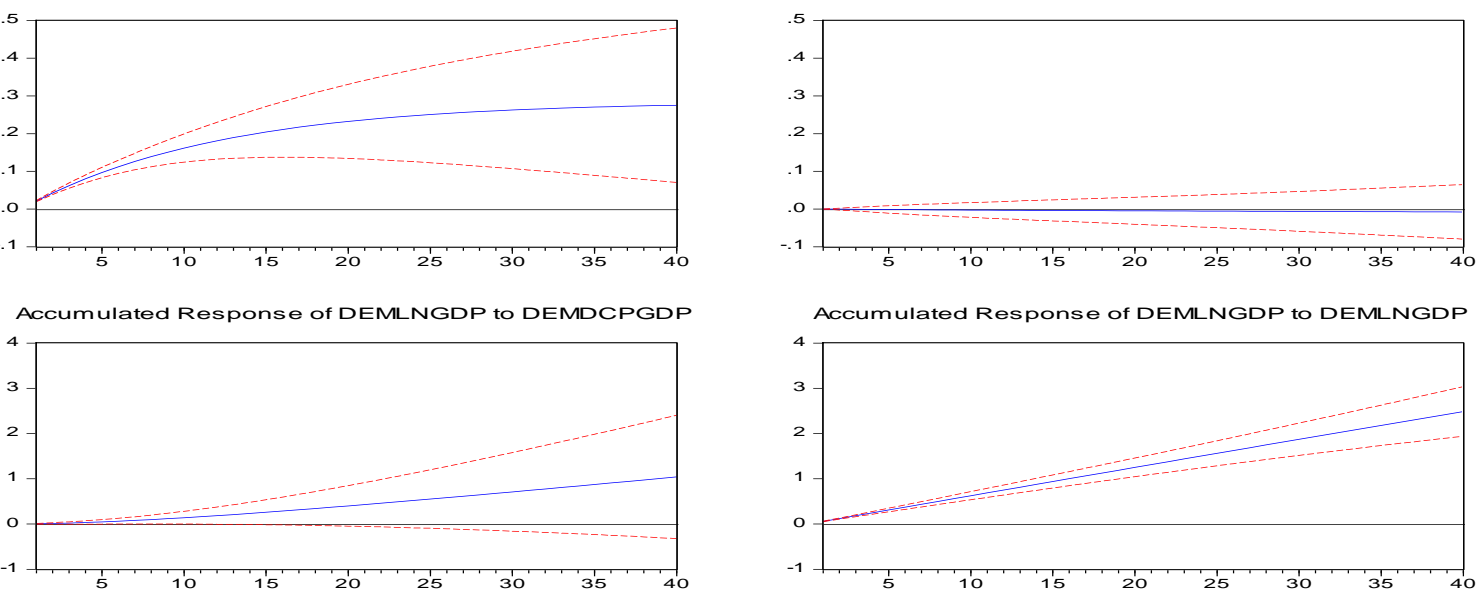

Fig.1. Accumulated Response of FS and real GDP

Note: DEMDCPGDP $\equiv F S$ and DEMLNGDP $\equiv$ real GDP in $\log$ form and DEMDCPGDP and DEMLNGDP represents demeaned data of FS and that of GDP, respectively.

\section{(cc) $\mathrm{Br}$}

This work is licensed under a Creative Commons Attribution 3.0 License. 